\title{
Review of Ecology-Based Strategy Change Theories
}

\author{
$\mathrm{Dan} \mathrm{Su}$ \\ School of Business Administration, Southwestern University of Finance and Economics \\ Chengdu 611130, China \\ E-mail: suninfeng7@163.com
}

\begin{abstract}
Researches on strategy change theories are sorted into two schools, namely the content school and the process school. Research methods include the organization adaptability method and the ecology method. In perspective of organizational ecology, this paper reviews representative literatures about strategy change theories and summarizes relevant research methods in this field, with the hope of evaluating the advantages and disadvantages of different research methods. In order to perfect the theory, this paper suggests an integrated research on complexity theory and ecology strategy change theory. Finally, this paper advances two development trends for the research on strategy change, with the hope of supplying a direction for management scholars' future research.
\end{abstract}

Keywords: Strategy change, Ecology, Complexity theory

\section{The concept of strategy change}

Strategy management scholars usually sort strategy change into tow schools, namely the content school and the process school (Amburgey, Kelly \& Barnett, 1993; Ginsberg, 1988; Meyer, Brooks \& Goes, 1990; Rajagopalan \& Spreitzer, 1996; Shortell, 1989). The content school chiefly studies strategy change's motives and results. The analyses are based on amounts of corporation samples and statistical data. The process school takes strategy change as a process of strategy constitution. They focus on the role of leaders in the process of strategy change (Rajagopalan \& Spreitzer, 1996).

Traditionally, most scholars think that strategy change happens frequently. It is triggered in a simple and flexible manner. They suppose the enterprise strategy is always in accordance with industrial environment. In other words, once environment changes, strategy must change in time (Smith \& Grimm, 1987; Zajac \& Shortell, 1989). In traditional strategy management, it is widely accepted that if enterprise strategy does not change along with the change of environment, the effect of organization will suffer from losses. As environment changes, the enterprise that adopts strategy change performs better than that not (Smith \& Grimm, 1987). There is an implicit assumption: strategy change will improve corporate performance by all means. So, we think that traditional strategy management holds an optimistic attitude to strategy change. However, is it the truth?

By researches we find that there are more failure cases than success cases in strategy change field in recent years. It indicates that strategy change's motives and results, differing from the traditional idea, are not easier. Significant changes of environment re-shape the industry and the border of enterprises. Driven by consumers' needs and technological progresses, the globalization has great impacts on all industries. Managers and scholars name the sharp change as "hypercompetitive" (Ilinitch, D'Aveni \& Lewin, 1996). In a hypercompetitive environment, we should study strategy change from a new perspective.

\section{The strategy change theory in perspective of ecology}

In late 70s, a new management study perspective, organizational ecology view, appears (Aldrich, 1979; Carroll, 1984; Hannan \& Freeman, 1977). Strategy management scholars introduce this view into researches on strategy change. Compared with traditional researches on strategy change, the ecology- based theory emphasizes on the effects of environmental changes on strategy change. Hannan and Freeman (1977) think that traditional organizational theory exaggerates the possibility degree of individual organization's basic evolvement. They argue to emphasize on similar organizations, namely "population", instead of one organization. In biology, Darwin (1859) tells us that the evolvement process is based on species or population. In evolvement process, the gene diversity in one population will be adjusted by popularization and procreation. And gene frequency changes accordingly. Therefore, along with changes of environment, all units in one population must adapt to new environment. Here, the "adaptability" is a repetitive evolvement process. So, the organizational ecology-based strategy change theory mainly discusses how species and population adapt to new environment. In other words, it studies how organizations evolve and survive from a "hypercompetitive" environment. 
This paper argues that the core of strategy change theory based on sharp environmental changes can be described by the "niche" concept. The niche is a set of environmental conditions in which a population can live and multiply. In other words, the niche includes a series of environmental conditions that make a population grow or survive. In organizational ecology, the niche means the set of relative conditions including the society, economy, and politics that are necessary for organizations' survival and growth (Min Luo, 2001).

In ecology-based strategy change theories, the most representative theory is the structural inertia model advanced by Hannan and Freeman (1984). This theory agrees that an organization's strategy is the "core competence" of the organization. The primary principle of the model is: an enterprise's internal pressure tends to prevent sharp changes of present strategy. In other words, organizational ecology scholars regard strategy as a stubborn tradition with inertia (Freeman and Boeker, 1984). They think that once the strategy is established, organizational leaders would not like to deviate from it (Robbins, 1990). Under this environment, corporate leaders are usually taken as being negative or symbolic (Pfeffer and Salancik, 1978). Because an enterprise's top managers often face internal enterprise pressures and external environment pressures, these pressures restrict their abilities of reforming the strategy. However, Weick and Starbuck think that no matter how sharp the external environment changes are, changes are reflected by managers' recognition. They lay stresses on managers' initiative behaviors in perspective of managers performing environment analysis. Here, we should not think that the ecology theory completely denies the influences of organizational top leaders and top managers on the strategy. Lots of enterprise cases show that organizational leaders and top managers have stronger initiatives for the execution of stategy as they determine to start a new commercial activity (such as develop new business) (Freeman and Boeker, 1984).

As for the effect of strategy change, organizational ecology scholars think that although corporate managers can make strategy change sometimes, and maintain the adaptability to environment, the strategy change is usually slower than environmental change. Then, in the process of strategy change, the risk for the die of enterprise is higher (Amburgey et al., 1993; Hannan \& Freeman, 1984, 1989; Haveman, 1992). According to the structural inertia theory, any change (such as strategy change) related with the core competence is extremely difficult. Therefore, in the process of strategy change, it may destroy the original organization system, disturb the connections of former interest-related parties, and decrease the efficiency and effect of the organization. Furthermore, it may lead to the decline of organizational performance, which will affect the survival of the organization in a short period at least (Baum and Amburgey, 2002, p310; Hannan and Freeman, 1984, 1989; Haveman, 1992, p48).

Although the change of core competence, such as strategy change, means higher risks, the reform of enterprise is necessary under the "hypercompetitive" environment (Baum \& Aburgey, 2002; Haveman, 1992; Haveman, Russo, and Meyer, 2001). Organizational ecology scholars also regard ecological density as important factors influencing strategy change. They think that the high-density industry can worsen the competition and the fierce competition will enhance all enterprises' strategy differentiation (Hannan and Freeman, 1989). Scholars think that it is difficult for enterprises development their products and services (change traditional strategy, develop new strategy and new business) in highdensity industries. In contrast, in a low-density environment, it is more possible for organizations occupying higher market shares by adjusting strategy (Boeker, 1991).

Besides, Hannan and Freeman $(1984,1989)$ think that according to the structural inertia model, the influencing factors of strategy change associate with not only the environment but also organizations' internal factors. For example, organization's age, size, and structural complexity connect with barriers of organizational strategy change.

As for organizational age, some scholars think that an organization can form an inherent institution and tradition in a long-term management and build a stable relationship with interest-related parties. Therefore, they think there is a monotone increasing relationship between strategy inertia and organization age (Ginsberg and Buchholtz, 1990; Hannan and Freeman, 1984). Therefore, as for adjusting competition strategy to adapt to environment needs, aged enterprises suffer from more restrictions. That is the age rigid assumption. However, some researchers point that aged, large-sized, and more complicated organizations may perform strategy change with higher possibilities. Just what is said by Boeker, because environmental changes need time, aged organizations have more experiences in dealing with environmental changes. "Aged" organizations will face more pressures as they change the original strategies. So, they prefer to adjust their strategies continuously in order to adapt to the changeable environment needs (Carroll, 1983). That is the so-called age flexibility assumption.

Researches on organization size result in a contrary conclusion either. In lots of researches, there is a positive correlation between organizational size and strategy change (Chatterjee and Wernerfelt, 1991; Haveman, 1993; Zajac and Kraatz, 1993; Barker and Duhaime, 1997; Zajac, et al., 2000; McDonald and Westphal, 2003; Washington and Ventresca, 2005). Therefore, these empirical studies serve as basis for size flexibility assumption (similar to the age flexibility assumption mentioned above). However, in other studies, there is a negative correlation between size and strategy change (Mitchell, 1989; Zúñiga- Vicente, et al., 2005). These empirical studies serve as basis for the size rigid assumption. Furthermore, some studies support both assumptions at the same time (Baum and Korn, 1996). Surely, 
some researches show that there is not a strong relationship between organizational size and strategy change (Ginsberg and Buchhloltz, 1990; Kelly and Amburgey, 1991; Aldrich, et al., 1994; Amburgey and Dancin, 1994; Haveman, et al., 2001).

Finally, Baum and Aburgey (2002) think that a complete organization change concept must take the organization's "history of change" into consideration because an organization tends to repeat its former change mode. In a sense, as an organization repeats its former change mode, we name this influencing factor as "organizational momentum" (Amburgey et al., 1993; Baum, 1996; Baum and Amburgey, 2002; Kelly and Amburgey, 1991; Miller and Friesen, 1984).

\section{The complexity theory}

Although this paper agrees that the strategy change theory that is based on organizational ecology is more practical than traditional theories, this theory has its defects. Organizational ecology is based on the natural selection theory, which is from Charles Robert Darwin's evolutionism. The evolutionism regards natural selection as the only engine for biological evolution, neglecting the possibility of complex system generating orders spontaneously. Therefore, this paper argues to introduce the complexity theory to complement the organizational ecology-based strategy change theory.

The complexity system theory regards the organization system as a swarm system. The so-called swarm system is an organic system that has life and can think. The system is self-organized (Bonabeau and Meyer, 2001). The complexity pattern thinks that evolvement of an organization and its operational model is under the influences of external environment, which is a natural selection process and associates with organizational biological system's internal components and factors' mutual relationship and interaction. The evolvement of an organization and its operational model is the result of natural selection and self-organization (Min Luo, 2006).

So we agree that enterprise's strategy change is a complex organizational behavior. Organizational strategy change is driven by the self-organization power generated by the interaction of external organization sources and organization's internal learning. The so-called "self-organize" refers to a process in which things become organized or ordered spontaneously. In other words, the self-organized system organizes, survives, evolves, innovates, and develops by itself without depending on external orders. It is a process from disorder to order. Under this circumstance, strategy change behavior includes not only transformation of enterprise's resource capabilities but also changes of organizational learning (Ancheng Pan, 2007). Macintosh and Maclean use the complexity theory to re-explain the motives for corporate strategy change. Robertson thinks that the self-organized process can help enterprise to improve the strategy change and adapt to changes of internal and external environment. Apparently, the complexity theory and the self-organize concept consider the influences of "hypercompetitive" environment and the initiative evolvement of organization. Therefore, to introduce the complexity theory into the research on strategy change theory is a right theoretical complement.

\section{Conclusion and prospect}

Today, the border of organizations tends to be fuzzier in the "hypercompetitive". The high failure rate of corporate strategy change arouses more thoughts on present strategy change theories. From analyses above, we know that there are also some paradoxes in the ecology-based strategy change theory. That is a difficulty in the research on strategy change. Here we should treat these paradoxes in perspective of contingency. We can classify enterprises according to different environments and backgrounds in researches. Then, the paradox becomes classification. Some scholars have already sorted the strategy change based on two dimensions, namely "mission prospect" and "industrial environment", and advanced a dominant logic matrix for strategy change (Xu Huang, 2004).

Besides, researches on the complexity of strategy change are short of support from empirical data. Therefore, we can predict that considerable empirical research methods and cases will appear in this field. For developing countries and regions, the empirical research on Chinese enterprises' strategy change since the reform and opening-up policy is valuable. Compared with conditions in developed countries, the market environment and relevant laws in developing countries change frequently, so do enterprises' strategy change and adjustment, especially for small and medium-sized enterprises. It will be a hot in the empirical researches on strategy change in the future.

\section{References}

Amburgey, T. L., Kelly, D. \& Barnett, W. P. (1993). Resetting the clock: The dynamics of organizational change and failure. Administrative Science Quarterly, 38, 1.

Baum, J.A.C. \& Amburgey, T. L. (2002). Organizational Ecology. In Baum, J. A. C. (Ed.). Companion to Organizations.

Freeman, J. \& Boeker, W. (1984). The ecological analysis of business strategy. California Management Review, $26,3$.

Ginsberg, A. \& Buchholtz, A. (1990). Converting to for-profit status: Corporate responsiveness to radical change. 
Academy of Management Journal, 33, 3.

Hannan, M. T. \& Freeman, J. (1977). The population ecology of organization. American Journal of Sociology, 82, 5.

Hannan, M. T. \& Freeman, J. (1989). Organizational Ecology. Cambridge, MA: Harvard University Press.

Haveman, H. A. (1992). Between a rock and a hard place: Organizational change and performance under conditions of fundamental environmental transformation. Administrative Science Quarterly, 37, 1.

Huang, Xu. (2004). Framework of dominant logic analysis for business strategic transformation under uncertainty environment. China Industrial Economy, No.11.

Ilinitch, A. I., D’Aveni, R. A. \& Lewin, A. Y. (1996). New organizational forms and strategies for managing in hypercompetitive environments. Organization Science, 7, 3.

José David Vicente-Lorente \& José Ángel Zúñiga-Vicente. (2008). Global Management: Strategy, Challenges, and Uncertainties. Nova Science Publishers.

Kauffman S A. (1995). At Home in the Universe: the Search for the Laws of Self2Organization and Comp Lexity [M]. New York: Oxford University Press.

Luo, Min. (2001). Population ecology: population adaptability organization theory. Foreign Economics \& Management, No. 10 .

Luo, Min. (2006). On new pattern of organizational theory. Science Research Management, No.3.

Meyer, A. D., Brooks, G. R. \& Goes, J. B. (1990). Environmental jolts and industry revolutions: Organizational responses to discontinuous change. Strategic Management Journal. No.11. special issue. summer,

Pan, Ancheng. (2007). Effects of strategic choice, organizational adaptation on firm growth: An empirical study in China. Journal of Management Sciences, No.20.

Rajagopalan, N. \& Spreitzer, G. M. (1996). Toward a theory of strategic change: A multilens- perspective and integrative framework. Academy of Management Review, 22, 1.

Robertson A. (2004). The comp lexity of the corporation. Human Systems Management, 23.

Smith, K. G. \& Grimm, C. M. (1987). Environmental variation, strategic change and firm performance: A study of railroad deregulation. Strategic Management Journal, 8, 4.

Zajac, E. J. \& Shortell, S. M. (1989). Changing generic strategies: Likelihood, direction, and performance implications. Strategic Management Journal, 10, 5. 